\title{
FRITZ, Johann, Die bewahrende Kraft des Luthertums. Mittelalterliche Kunstwerke in evangelischen Kirchen
}

\section{Olivier Christin}

\section{OpenEdition}

\section{Journals}

Édition électronique

URL : http://journals.openedition.org/ifha/1318

DOl : 10.4000/ifha.1318

ISSN : 2198-8943

Éditeur

IFRA - Institut franco-allemand (sciences historiques et sociales)

Référence électronique

Olivier Christin, «FRITZ, Johann, Die bewahrende Kraft des Luthertums. Mittelalterliche Kunstwerke in evangelischen Kirchen », Revue de l'IFHA [En ligne], Date de recension, mis en ligne le 01 janvier 2000 consulté le 22 septembre 2020. URL : http://journals.openedition.org/ifha/1318 ; DOI : https://doi.org/ 10.4000/ifha.1318

Ce document a été généré automatiquement le 22 septembre 2020.

(C)IFHA 


\title{
FRITZ, Johann, Die bewahrende Kraft des Luthertums. Mittelalterliche Kunstwerke in evangelischen Kirchen
}

\author{
Olivier Christin
}

Ce petit livre, très bien illustré, rassemble cinq contributions présentées dans la section d'histoire de l'art lors de l'assemblée de la Görres-Gesell-schaft en 1995. Elles concernent la survie des œuvres d'art médiévales dans les églises luthériennes, notamment à Nuremberg, à Halberstadt, dans le Mecklembourg. Deux textes plus généraux et une sélection de 80 photographies commentées complètent l'ensemble.

Le sujet de ce recueil, apparemment paradoxal, n'est pas sans intérêt une fois dépouillé de quelques oripeaux confessionnels et de quelques affirmations à l'emporte-pièce. Inventorier les statues, les retables, les ornements du Moyen Âge conservés dans les églises luthériennes, décrire les conditions mêmes de leur préservation et le nouveau statut qui fut le leur une fois abolies les pratiques religieuses (messes, culte des saints, processions, prières pour les morts...) pour lesquelles ils avaient été forgés, c'est en effet aborder un aspect peu connu de la Réformation et de la querelle des images au XVIe s. Prédicateurs, conseils de ville, communautés, héritiers des pieux donateurs, religieux encore présents dans certains lieux et sous certaines conditions, agissent de façon extrêmement prudente et nuancée. À Nuremberg, par exemple, G. SEEBASS souligne le sort bien différent des images et des ornements selon qu'ils se trouvent dans des églises paroissiales, des Klosterkirchen ou des monastères, les premières paraissant conserver plus largement et plus durablement leur décor médiéval. Ventes, restitutions aux héritiers des donateurs, fontes de reliquaires, destructions pures et simples ne sont donc ni une règle impérieuse ni même une politique méthodique, mais le résultat de choix pragmatiques, de décisions au cas par cas.

Plus que les analyses générales sur le pouvoir conservatoire du luthéranisme ou l'analyse classique de la théologie luthérienne de l'image, on retiendra donc l'intérêt des enquêtes locales et la qualité du dossier iconographique. On reste toutefois loin de 
ce que propose depuis novembre 2000 l'exposition Bildersturm à Berne sous la direction de Peter Jezler.

Olivier CHRISTIN 